Laser Chem. 1988, Vol. 8, pp. 259-274

(C) 1988 Harwood Academic Publishers GmbH

Photocopying permitted by license only

Reprints available directly from the Publisher

Printed in the United Kingdom

\title{
Kinetics and Mechanism of Transformations of Aliphatic Alcohol Molecules under Multiphoton IR Excitation
}

\author{
G. P. ZHITNEVA, I. A. MARKINA and S. A. PSHEZHETSKII \\ Karpov Institute of Physical Chemistry, ul. Obukha 10, Moscow 107120
}

(Received October 2, 1987; in final form November 25, 1987)

The main channels for transformations of $\mathrm{C}_{2} \mathrm{H}_{5} \mathrm{OH}$, iso- $\mathrm{CH}_{3} \mathrm{H}_{7} \mathrm{OH}$ and $n-\mathrm{C}_{3} \mathrm{H}_{7} \mathrm{OH}$ molecules under IR multiphoton excitation are the monomolecular reactions of dehydration (1), and $\mathrm{C}_{\alpha}-\mathrm{C}_{\beta}$ bond breaks (2). The ratio of the yields of reactions (1) and (2), $\gamma$, is determined by the molecules' structure, radiation energy density, the pressure of alcohol vapors and inert gas. The direction of the alcohol molecules' transformations under IR MPE, under thermal equilibrium conditions, differs from pyrolysis, when the chain processes of $\mathrm{C}_{2} \mathrm{H}_{5} \mathrm{OH}$ and $\mathrm{C}_{3} \mathrm{H}_{7} \mathrm{OH}$ molecules dehydrogenation, and $\mathrm{CH}_{4}$ splitting-out from $n-\mathrm{C}_{3} \mathrm{H}_{7} \mathrm{OH}$ molecules are developing. Reactions of $\mathrm{H}$ and $\mathrm{CH}_{3}$ radicals with alcohol molecules under laser initiation do not lead to the development of chains due to the high rate of $\mathrm{H}$ atoms diffusion from reaction zone and effective recombination of $\mathrm{CH}_{3}$ radicals.

KEY WORDS: $\mathrm{C}_{2} \mathrm{H}_{5} \mathrm{OH}$, iso- $\mathrm{CH}_{3} \mathrm{H}_{7} \mathrm{OH}, \mathrm{n}-\mathrm{C}_{3} \mathrm{H}_{7} \mathrm{OH}$, pyrolysis.

\section{INTRODUCTION}

Under pulsed laser IR irradiation of organic molecules a reaction can proceed simultaneously by several channels characterized by different energy barriers. Two main cases may be distinguished:

1. The reaction runs by molecular elimination mechanism.

2. The reaction results from the chemical bond's dissociation and consequent transformations of radicals. 
The ratio of the yields of these processes depends on several factors including the height of energy barriers, peculiarities of molecule structure, as well as radiation energy density and gas pressure. The first path is typical of laser chemistry, as will be shown below; the second is similar to the chain processes beginning. Of special interest to laser chemistry is studying the problem of the relation of the two paths, which is directly related with the problem of selectivity. We have studied this problem for some aliphatic alcohols, $\mathrm{R}_{1} \mathrm{R}_{2} \mathrm{CHOH}$, differing by the carbon chain length and structure, under varying pressure and radiation energy density. The $\mathrm{R}_{1} \mathrm{R}_{2} \mathrm{CHOH}$ molecules can undergo the monomolecular reaction of dehydration

$$
\mathrm{R}_{1} \mathrm{R}_{2} \mathrm{CHOH} \longrightarrow \mathrm{H}_{2} \mathrm{O}+\mathrm{CH}_{2}=\mathrm{CH}_{2}
$$

as well as $\mathrm{C}-\mathrm{C}$ bond break

$$
\mathrm{R}_{1} \mathrm{R}_{2} \mathrm{CHOH} \longrightarrow \mathrm{R}_{1}+\mathrm{R}_{2} \mathrm{CHOH}
$$

The latter is capable of initiating the chain processes ${ }^{1-3}$ by pattern 1 . The direction of transformations is determined by the ratio of the rates of primary reactions (1) and (2), and by the probability of chain development.

The major processes involved in pyrolysis of these alcohols $(800$ $900 \mathrm{~K}$ ) are chain dehydrogenation of $\mathrm{C}_{2} \mathrm{H}_{5} \mathrm{OH}$ and iso- $\mathrm{C}_{3} \mathrm{H}_{7} \mathrm{OH}$, and detachment of $\mathrm{CH}_{4}$ with $n-\mathrm{C}_{3} \mathrm{H}_{7} \mathrm{OH}$. Pulsed laser induced reactions go under specific conditions of collisionless processes with a localized reaction zone. These conditions hinder chain propagation and there-

$$
\begin{aligned}
& \mathrm{R}_{1}+\mathrm{R}_{1} \mathrm{R}_{2} \mathrm{CHOH} \rightarrow \mathrm{R}_{1} \mathrm{H}+\mathrm{R}_{1} \mathrm{R}_{2} \mathrm{COH} \\
& \mathrm{R}_{1} \mathrm{R}_{2} \mathrm{COH} \rightarrow \mathrm{H}+\mathrm{R}_{1} \mathrm{R}_{2} \mathrm{CO} \text { (with } \mathrm{C}_{2} \mathrm{H}_{5} \mathrm{OH} \text { and iso- } \mathrm{C}_{3} \mathrm{H}_{7} \mathrm{OH} \text { ) (4a) } \\
& \mathrm{R}_{1} \mathrm{R}_{2} \mathrm{COH} \rightarrow \mathrm{CH}_{3}+\mathrm{CH}_{3} \mathrm{CHO} \text { (with n- } \mathrm{C}_{3} \mathrm{H}_{7} \mathrm{OH} \text { ) } \\
& \mathrm{H}+\mathrm{R}_{1} \mathrm{R}_{2} \mathrm{CHOH} \rightarrow \mathrm{H}_{2}+\mathrm{R}_{1} \mathrm{R}_{2} \mathrm{COH} \\
& \mathrm{CH}_{3}+\mathrm{R}_{1} \mathrm{R}_{2} \mathrm{CHOH} \rightarrow \mathrm{CH}_{4}+\mathrm{R}_{1} \mathrm{R}_{2} \mathrm{COH} \\
& \mathrm{H}+\mathrm{H}+\mathrm{M} \rightarrow \mathrm{H}_{2}+\mathrm{M} \\
& \mathrm{CH}+\mathrm{CH}_{3}+\mathrm{CH}_{3}+\mathrm{M} \rightarrow \mathrm{C}_{2} \mathrm{H}_{6}+\mathrm{M} \\
& \left(\mathrm{Here} \mathrm{R}_{1}=\mathrm{CH}_{3}, \mathrm{R}_{2}=\mathrm{H} \text { for } \mathrm{C}_{2} \mathrm{H}_{5} \mathrm{OH}, \mathrm{R}_{2}=\mathrm{H}\right. \text { for } \\
& n-\mathrm{C}_{3} \mathrm{H}_{7} \mathrm{OH}, \mathrm{R}_{1}=\mathrm{R}_{2}=\mathrm{CH}_{3} \text { for iso- } \mathrm{C}_{3} \mathrm{H}_{7} \mathrm{OH}, \mathrm{R}=\mathrm{H} \\
& \text { for } \left.\mathrm{C}_{2} \mathrm{H}_{5} \mathrm{OH} \text { and } \mathrm{R}=\mathrm{CH}_{3} \text { for } n-\text { and iso- } \mathrm{C}_{3} \mathrm{H}_{7} \mathrm{OH}\right)
\end{aligned}
$$

Pattern 1 Chain reactions in aliphatic alcohols. 
fore, such transformations can be expected to follow mechanisms other than pyrolysis. Our purpose is to investigate general reaction patterns for compounds of a given class and determine the dependence of reaction directions on molecular structures.

\section{EXPERIMENTAL}

A pulsed transverse-discharge $\mathrm{CO}_{2}$ laser $\left(\tau_{\text {pulse }}=180 \mathrm{~ns}\right.$, $E_{\text {pulse }}=0.06 \mathrm{~J}$ ) operating at the $9 \mathrm{R}(16) 1050 \mathrm{~cm}^{-1}$ line, the resonance frequency of $\mathrm{C}-\mathrm{O}$ stretching vibrations, was employed. Laser energy density was varied using $\mathrm{BaF}_{2}$ lenses with focal distances of 5.0, 12.5 and $25.0 \mathrm{~cm}$. Alcohol vapours were irradiated in a quartz cell with $\mathrm{BaF}_{2}$ windows $(1=5.0, \mathrm{~d}=1.5 \mathrm{~cm})$. In some experiments they were diluted with an inert gas such as helium or nitrogen. The role played by radicals in the formation of reaction products was studied using mixtures of alcohol vapours with $\mathrm{O}_{2}$ as radical scavenger. Low oxygen partial pressures $(\leqslant 100 \mathrm{~Pa})$ were used to minimize oxygen effects on excitation of alcohol molecules during a pulse. Reaction products were analyzed after irradiation by gas chromatographing with Polysorb-1 or $13 \mathrm{X}$ molecular sieves as adsorbents. The compounds detected were: $\mathrm{C}_{2} \mathrm{H}_{4}, \mathrm{CH}_{3} \mathrm{CHO}, \mathrm{C}_{2} \mathrm{H}_{6}$, and $\mathrm{CH}_{4}$ for $\mathrm{C}_{2} \mathrm{H}_{5} \mathrm{OH} ; \mathrm{C}_{3} \mathrm{H}_{6}, \mathrm{C}_{2} \mathrm{H}_{4}, \mathrm{C}_{2} \mathrm{H}_{6}$, $\mathrm{CH}_{4}, \mathrm{C}_{3} \mathrm{H}_{8}, \mathrm{C}_{4} \mathrm{H}_{10}, \mathrm{CH}_{3} \mathrm{CHO}$ and $\mathrm{CH}_{3} \mathrm{CH}_{2} \mathrm{CHO}$ for $\mathrm{n}-\mathrm{C}_{3} \mathrm{H}_{7} \mathrm{OH}$; $\mathrm{C}_{3} \mathrm{H}_{6}, \mathrm{C}_{2} \mathrm{H}_{6}, \mathrm{CH}_{4}, \mathrm{CH}_{3} \mathrm{CHO}, \mathrm{CH}_{3} \mathrm{COCH}_{3}, \mathrm{C}_{2} \mathrm{H}_{4}$, and $\mathrm{C}_{4} \mathrm{H}_{6}$ for iso$\mathrm{C}_{3} \mathrm{H}_{7} \mathrm{OH}$.

\section{RESULTS AND DISCUSSION}

The dependences of reaction product yields $\phi(\mathrm{X})$ on alcohol vapour pressure $\mathrm{P}$ are shown in Figure 1. The yields $\phi(\mathrm{X})$ are given per unit vapour pressure and one pulse. The transition from collisionless conditions to collision ones occurs at 30-50 Pa. Independence of $\phi(\mathrm{X})$ from $\mathrm{P}$ and the absence of products formed in reactions between molecules and radicals (3) (e.g. $\mathrm{CH}_{4}$ with $\mathrm{C}_{2} \mathrm{H}_{5} \mathrm{OH}$ ) have been used as criteria of collisionless conditions. The absence of products from reactions between radicals and molecules is indicative of only insignificant heating of the reaction zone after a pulse, for the activation energy of such reactions is equal to $\sim 40 \mathrm{~kJ} / \mathrm{mol}$. The additon of $\mathrm{O}_{2}$ to alcohol 

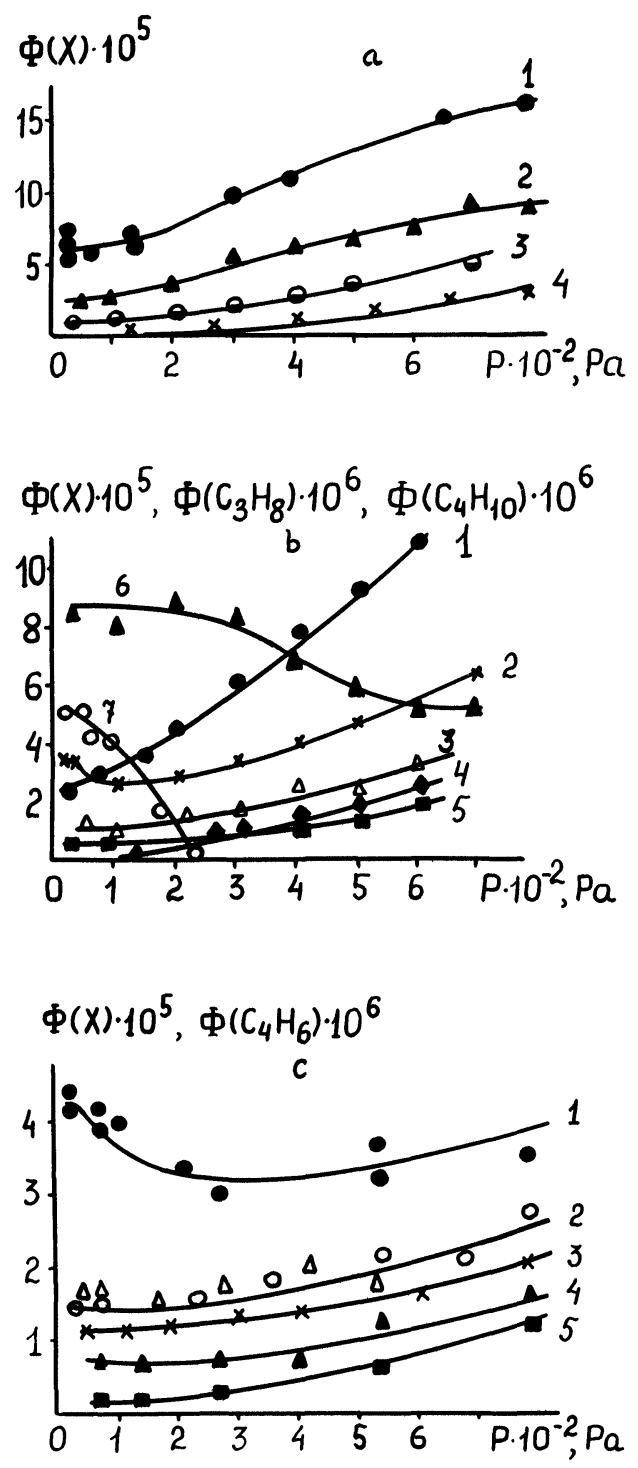

Figure 1 The dependence of product yields, $\phi(\mathrm{X})$, on $\mathrm{P}_{\text {alcohol }}:(\mathrm{a}) \phi\left(\mathrm{C}_{2} \mathrm{H}_{4}\right)(1), \phi(\mathrm{C}-\mathrm{C})$ (2), $\phi\left(\mathrm{CH}_{3} \mathrm{CHO}\right)(3), \phi\left(\mathrm{CH}_{4}\right)$ (4) vs. $\mathrm{P}_{\mathrm{C}_{2} \mathrm{H}_{5} \mathrm{OH}}$; (b) $\phi\left(\mathrm{C}_{2} \mathrm{H}_{4}\right)(1), \phi\left(\mathrm{C}_{3} \mathrm{H}_{6}\right)(2), \phi\left(\mathrm{C}_{2} \mathrm{H}_{6}\right)(3)$, $\phi\left(\mathrm{CH}_{4}\right)(4), \phi\left(\mathrm{CH}_{3} \mathrm{CHO}\right)(5), \phi\left(\mathrm{C}_{3} \mathrm{H}_{8}\right)(6), \phi\left(\mathrm{C}_{4} \mathrm{H}_{10}\right)(7)$ vs. $\mathrm{P}_{\mathrm{n}-\mathrm{C}_{3} \mathrm{H}_{7} \mathrm{OH}}$ (c) $\phi\left(\mathrm{C}_{3} \mathrm{H}_{6}\right)(1)$, $\phi\left(\mathrm{C}_{2} \mathrm{H}_{6}\right)$ and $\phi\left(\mathrm{CH}_{3} \mathrm{CHO}\right)(2), \phi\left(\mathrm{C}_{4} \mathrm{H}_{6}\right)(3), \phi\left(\mathrm{CH}_{4}\right)(4), \phi\left(\mathrm{C}_{2} \mathrm{H}_{4}\right)(5)$ vs. $\mathrm{P}_{\text {iso- } \mathrm{C}_{3} \mathrm{H}_{7} \mathrm{OH}}$. 
vapours results in a decrease of $\phi\left(\mathrm{CH}_{4}\right)$ and $\phi\left(\mathrm{C}_{2} \mathrm{H}_{6}\right)$ for $\mathrm{C}_{2} \mathrm{H}_{5} \mathrm{OH}$; $\phi\left(\mathrm{C}_{2} \mathrm{H}_{6}\right)$ for iso- $\mathrm{C}_{3} \mathrm{H}_{7} \mathrm{OH}$; and $\phi\left(\mathrm{C}_{2} \mathrm{H}_{6}\right), \phi\left(\mathrm{C}_{3} \mathrm{H}_{8}\right)$ and $\phi\left(\mathrm{C}_{4} \mathrm{H}_{10}\right)$ for $\mathrm{n}-\mathrm{C}_{3} \mathrm{H}_{7} \mathrm{OH}$ (typical results are represented in Figure 2). This is indicative of the participation of radicals in the formation of these products.

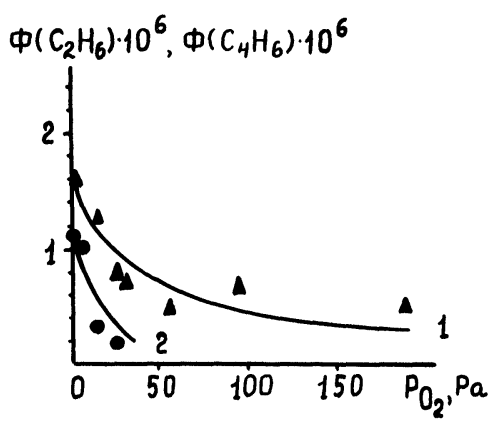

Figure 2 The dependence of $\mathrm{C}_{2} \mathrm{H}_{6}$ (1) and $\mathrm{C}_{4} \mathrm{H}_{6}$ (2) yields on $\mathrm{P}_{\mathrm{O}_{2}}$ in IR MPE of iso- $\mathrm{C}_{3} \mathrm{H}_{7} \mathrm{OH}$.

\section{Collisionless conditions}

Product yields from reactions that run under collisionless conditions are listed in Table I. Consideration of product compositions and $\mathrm{O}_{2}$ effects on product yields shows that collisionless reactions of alcohol

Table I Product yields, $\phi(\mathrm{X})$, in IR MPE of alcohol molecules under collisionless conditions.

\begin{tabular}{llll}
\hline$\phi(\mathrm{X}) \cdot 10^{5}$ & $\mathrm{n}_{2} \mathrm{C}_{5} \mathrm{OH}$ & $\mathrm{H}_{7} \mathrm{OH}$ & iso- $\mathrm{C}_{3} \mathrm{H}_{7} \mathrm{OH}$ \\
\hline rel. units & 6.3 & 2.2 & - \\
$\phi\left(\mathrm{C}_{2} \mathrm{H}_{4}\right)$ & - & 3.2 & 4.4 \\
$\phi\left(\mathrm{C}_{3} \mathrm{H}_{6}\right)$ & - & 0.1 & 0.4 \\
$\phi\left(\mathrm{CH}_{4}\right)$ & 2.5 & 0.75 & 1.5 \\
$\phi\left(\mathrm{C}_{2} \mathrm{H}_{6}\right)$ & - & 1.0 & - \\
$\phi\left(\mathrm{C}_{3} \mathrm{H}_{8}\right)$ & - & 0.5 & - \\
$\phi\left(\mathrm{C}_{4} \mathrm{H}_{10}\right)$ & - & 0.5 & 1.8 \\
$\phi\left(\mathrm{CH}_{3} \mathrm{CHO}\right)$ & - & - & 0.4 \\
$\phi\left(\mathrm{CH}_{3} \mathrm{COCH}_{3}\right)$ & - & 1.0 & - \\
$\phi\left(\mathrm{CH}_{3} \mathrm{CH}_{2} \mathrm{CHO}\right)$ & - & & \\
\hline
\end{tabular}


molecules under IR MPE may include:

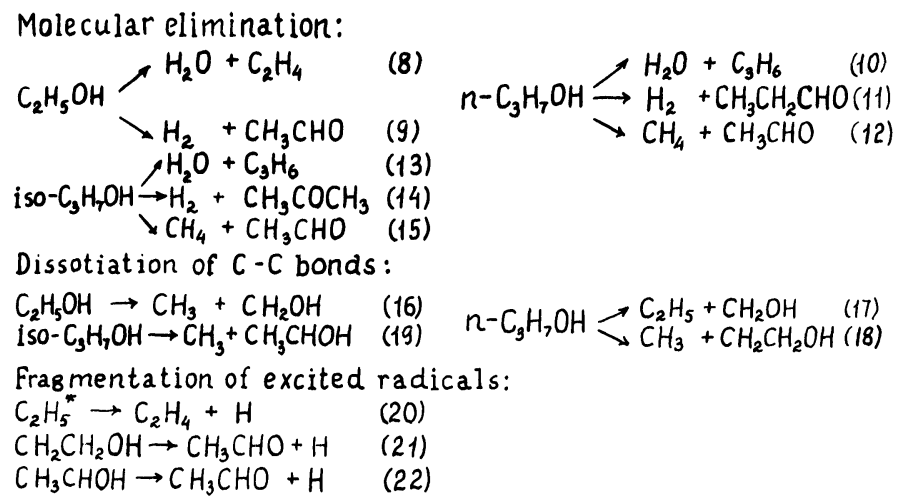

Pattern 2 Monomolecular reactions in the absence of collisions.

The occurrence of reactions (21) and (22) follows from the product ratio $\phi\left(\mathrm{CH}_{3} \mathrm{CHO}\right)>\phi\left(\mathrm{CH}_{4}\right)$ observed for $n-\mathrm{C}_{3} \mathrm{H}_{7} \mathrm{OH}$ and iso- $\mathrm{C}_{3} \mathrm{H}_{7} \mathrm{OH}$ under IR MPE. Radicals $\mathrm{C}_{2} \mathrm{H}_{5}, \mathrm{CH}_{2} \mathrm{CH}_{2} \mathrm{OH}$, and $\mathrm{CH}_{3} \mathrm{CHOH}$ obtain excitation energy required for reactions (20) to (22) either in the dissociation of excited alcohol molecules or as a result of IR MPE of radicals formed during a laser pulse (the rocking vibration frequency of the $\mathrm{CH}_{3}$ group in radical $\mathrm{C}_{2} \mathrm{H}_{5}$ and the stretching vibration frequency of the $\mathrm{C}-\mathrm{O}$ bond in radicals $\mathrm{CH}_{2} \mathrm{CH}_{2} \mathrm{OH}$ and $\mathrm{CH}_{3} \mathrm{CHOH}$ are in resonance with the $1050 \mathrm{~cm}^{-1}$ laser radiation frequency). Radicals $\mathrm{CH}_{3}$ and $\mathrm{C}_{2} \mathrm{H}_{5}$ formed in the dissociation of $\mathrm{C}-\mathrm{C}$ bonds (reactions (16) to (19)) participate in recombination reactions which occur after laser pulses. This is substantiated by a decrease in $\phi\left(\mathrm{C}_{2} \mathrm{H}_{6}\right), \phi\left(\mathrm{C}_{3} \mathrm{H}_{8}\right)$ and $\phi\left(\mathrm{C}_{4} \mathrm{H}_{10}\right)$ at oxygen pressures below $100 \mathrm{~Pa}$, for the time between molecule collisions is then greater than the pulse time:

$$
\begin{aligned}
& \mathrm{CH}_{3}+\mathrm{CH}_{3}+\mathrm{M} \text { (or wall) } \longrightarrow \mathrm{C}_{2} \mathrm{H}_{6}+\mathrm{M} \text { (or wall) } \\
& \mathrm{CH}_{3}+\mathrm{C}_{2} \mathrm{H}_{5}+\mathrm{M} \text { (or wall) } \longrightarrow \mathrm{C}_{3} \mathrm{H}_{8}+\mathrm{M} \text { (or wall) } \\
& \mathrm{C}_{2} \mathrm{H}_{5}+\mathrm{C}_{2} \mathrm{H}_{5}+\mathrm{M} \text { (or wall) } \longrightarrow \mathrm{C}_{4} \mathrm{H}_{10}+\mathrm{M} \text { (or wall) }
\end{aligned}
$$

The yield from $\mathrm{C}_{\alpha}-\mathrm{C}_{\beta}$ bond dissociation reactions, $\phi\left(\mathrm{C}_{\alpha}-\mathrm{C}_{\beta}\right)$, is equal to twice the $\phi\left(\mathrm{C}_{2} \mathrm{H}_{6}\right)$ value for $\mathrm{C}_{2} \mathrm{H}_{5} \mathrm{OH}$ and iso- $\mathrm{C}_{3} \mathrm{H}_{7} \mathrm{OH}$; and for $\mathrm{n}-\mathrm{C}_{3} \mathrm{H}_{7} \mathrm{OH}, \phi\left(\mathrm{C}_{\alpha}-\mathrm{C}_{\beta}\right)=\phi\left(\mathrm{C}_{2} \mathrm{H}_{4}\right)+\phi\left(\mathrm{C}_{3} \mathrm{H}_{8}\right)+2 \phi\left(\mathrm{C}_{4} \mathrm{H}_{10}\right)$ 
Table II Yields of elimination and $\mathrm{C}_{\alpha}-\mathrm{C}_{\beta}$ bond dissociation reactions. $E=0.06 \mathrm{~J}, f=$ $5.0 \mathrm{~cm}$.

\begin{tabular}{llll}
\hline$\phi^{\mathrm{a}}$, rel. units & $\mathrm{C}_{2} \mathrm{H}_{5} \mathrm{OH}$ & $\mathrm{n}-\mathrm{C}_{3} \mathrm{H}_{7} \mathrm{OH}$ & iso- $\mathrm{C}_{3} \mathrm{H}_{7} \mathrm{OH}$ \\
\hline$\phi\left(\mathrm{H}_{2} \mathrm{O}\right)$ & 0.63 & 0.28 & 0.54 \\
$\phi\left(\mathrm{H}_{2}\right)$ & 0.08 & 0.08 & 0.06 \\
$\phi\left(\mathrm{CH}_{4}\right)$ & - & 0.01 & 0.05 \\
$\phi\left(\mathrm{C}_{\alpha}-\mathrm{C}_{\beta}\right)$ & 0.32 & 0.39 & 0.35 \\
$\phi\left(\mathrm{C}_{\beta}-\mathrm{C}_{\gamma}\right)$ & - & 0.24 & - \\
$\phi_{\Sigma}(\mathrm{C}-\mathrm{C})$ & 0.32 & 0.63 & 0.35
\end{tabular}

${ }^{\mathrm{a}} \phi$ is the elimination or $\mathrm{C}-\mathrm{C}$ bond dissociation reaction to the total product yield ratio.

Table III Rate constants of IR MPE-induced reactions under collisionless conditions.

\begin{tabular}{llcl}
\hline Alcohol & $\left.k_{\left(\mathrm{H}_{2} \mathrm{O}\right.}\right) \cdot 10^{-7}, \mathrm{~s}^{-1}$ & $k_{\left(\mathrm{C}_{\alpha}-\mathrm{C}_{\beta}\right)} \cdot 10^{-7}, \mathrm{~s}^{-1}$ & $k_{\left(\mathrm{C}_{\beta}-\mathrm{C}_{\gamma}\right)} \cdot 10^{-7}, \mathrm{~s}^{-1}$ \\
\hline $\mathrm{C}_{2} \mathrm{H}_{5} \mathrm{OH}$ & 3.6 & $3.6( \pm 1.0)$ & - \\
$\mathrm{n}-\mathrm{C}_{3} \mathrm{H}_{7} \mathrm{OH}$ & $0.8( \pm 0.3)$ & $2.7( \pm 0.8)$ & $0.6( \pm 0.2)$ \\
iso- $\mathrm{C}_{3} \mathrm{H}_{7} \mathrm{OH}$ & not defined & $32( \pm 6)$ & - \\
\hline
\end{tabular}

and $\phi\left(\mathrm{C}_{\beta}-\mathrm{C}_{\gamma}\right)=2 \phi\left(\mathrm{C}_{2} \mathrm{H}_{6}\right)+\phi\left(\mathrm{C}_{3} \mathrm{H}_{8}\right)$. Table II contains relative contributions from various IR MPE-induced reactions to the total decomposition yield. One can see that the process is dominated by dehydration reaction (1) and $\mathrm{C}_{\alpha}-\mathrm{C}_{\beta}$ bond dissociation reaction (2). Under IR MPE conditions, the major decomposition path is dehydration for $\mathrm{C}_{2} \mathrm{H}_{5} \mathrm{OH}$ and iso- $\mathrm{C}_{3} \mathrm{H}_{7} \mathrm{OH}$ and $\mathrm{C}_{\alpha}-\mathrm{C}_{\beta}$ bond dissociation for $\mathrm{n}-\mathrm{C}_{3} \mathrm{H}_{7} \mathrm{OH}$.

The rate constants of IR MPE-induced reactions are listed in Table III. These are calculated from reaction product yield dependences on $\mathrm{P}_{\mathrm{He}, \mathrm{N}_{2}}$ (typical results are shown in Figure 3 ) using the equation ${ }^{4}$

$$
k=Z_{0} P_{1 / 2}
$$

where $k$ is the reaction rate constant,

$Z_{0}$ the specific frequency of deactivating collisions,

$P_{1 / 2}$ the inert gas $\left(\mathrm{He}\right.$ or $\left.\mathrm{N}_{2}\right)$ pressure corresponding to a twofold decrease in the reaction product yield.

One can see from Table III that for $\mathrm{C}_{2} \mathrm{H}_{5} \mathrm{OH}$ and iso- $\mathrm{C}_{3} \mathrm{H}_{7} \mathrm{OH}$, the dehydration rate constant exceeds the rate constant of $\mathrm{C}_{\alpha}-\mathrm{C}_{\beta}$ bond dissociation, while the latter reaction is faster than the former one in $\mathrm{n}-\mathrm{C}_{3} \mathrm{H}_{7} \mathrm{OH}$. The pre-exponential factors and activation energies for dehydration (1) and $\mathrm{C}_{\alpha}-\mathrm{C}_{\beta}$ bond dissociation (2) reactions in alcohols are listed in Table IV. The pre-exponential factors for dehydration of 


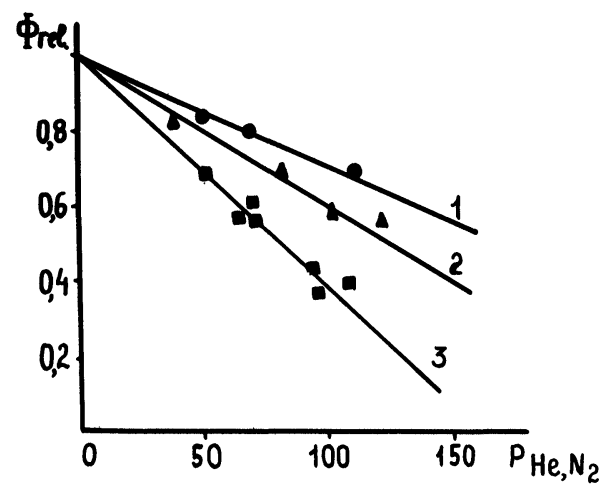

Figure 3 The dependence of relative $\mathrm{CH}_{3} \mathrm{CHO}$ yield on $\mathrm{P}_{\mathrm{He}}(1)$ and $\mathrm{P}_{\mathrm{N}_{2}}(2)$ and $\mathrm{C}_{2} \mathrm{H}_{6}$ yield on $\mathrm{P}_{\mathrm{He}}(3)$ in IR MPE of $\mathrm{C}_{2} \mathrm{H}_{5} \mathrm{OH}, f=5.0 \mathrm{~cm}$.

Table IV Pre-exponential factors and activation energies for dehydration (1), $\mathrm{C}_{\alpha}-\mathrm{C}_{\beta}$ bond dissociation (2), and $\mathrm{C}_{\beta}-\mathrm{C}_{\gamma}$ bond dissociation reactions in alcohols.

\begin{tabular}{lllllll}
\hline Alcohol & $\begin{array}{l}E_{1} \\
\mathrm{~kJ} / \mathrm{mol}\end{array}$ & $1 \mathrm{~g} A_{1}$ & $\begin{array}{l}E_{2} \\
\mathrm{~kJ} / \mathrm{mol}\end{array}$ & $1 \mathrm{~g} A_{2}$ & $\begin{array}{l}E_{\mathrm{C}_{\beta}-\mathrm{C}_{y}} \\
\mathrm{~kJ} / \mathrm{mol}\end{array}$ & $1 \mathrm{~g} A_{\mathrm{C}_{\beta}-} \mathrm{C}_{y}$ \\
\hline $\mathrm{C}_{2} \mathrm{H}_{5} \mathrm{OH}$ & $288^{5}$ & $13.4^{5}$ & $355^{5}$ & $16.0^{5}$ & - & - \\
$\mathrm{n}^{-\mathrm{C}_{3} \mathrm{H}_{7} \mathrm{OH}}$ & 288 & 13.2 & $342^{6}$ & $16.0^{7}$ & $357^{6}$ & $16.6^{6}$ \\
iso- $\mathrm{C}_{3} \mathrm{H}_{7} \mathrm{OH}$ & 273 & 13.7 & $339^{8}$ & 16.3 & - & - \\
\hline
\end{tabular}

n- and iso- $\mathrm{C}_{3} \mathrm{H}_{7} \mathrm{OH}$ were estimated from the $A_{1}$ value for $\mathrm{C}_{2} \mathrm{H}_{5} \mathrm{OH}$ using the equation $A_{1, \mathrm{ROH}} / A_{1, \mathrm{C}_{2} \mathrm{H}_{5} \mathrm{OH}}=\exp \Delta S^{+} / R^{9}$ where $\Delta S^{+}=$ $\Delta S_{\mathrm{ROH}}-\Delta S_{\mathrm{C}_{2} \mathrm{H}_{5} \mathrm{OH}}$. The quantities $\Delta S_{\mathrm{ROH}}$ and $\Delta S_{\mathrm{C}_{2} \mathrm{H}_{5} \mathrm{OH}}$ are the entropy changes corresponding to transition states in dehydration of nor iso- $\mathrm{C}_{3} \mathrm{H}_{7} \mathrm{OH}$ and $\mathrm{C}_{2} \mathrm{H}_{5} \mathrm{OH}$, respectively. Transition states were assigned the structures of four-centre cyclic complexes:

$$
\mathrm{H}_{2} \mathrm{C}-\mathrm{CH}_{2}
$$

$\mathrm{H} \cdot \mathrm{OH}$<smiles>CCC</smiles>

$\mathrm{H} \cdot \mathrm{OH}$

$$
\mathrm{H}_{3} \mathrm{C}-\mathrm{C}(\mathrm{H})-\mathrm{CH}_{2}
$$$$
\mathrm{H} \cdot \mathrm{O}
$$

The major contribution to $\Delta S^{+}$results from entropy changes associated with changes in molecular symmetry $\left(\Delta S_{\mathrm{sym}} \cdot \mathrm{C}_{2} \mathrm{H}_{5} \mathrm{OH}=R \ln 3\right.$, $\Delta S_{\text {sym.n- } \mathrm{C}_{3} \mathrm{H}_{7} \mathrm{OH}}=R \ln 2$, and $\Delta S_{\text {sym.iso- } \mathrm{C}_{3} \mathrm{H}_{7} \mathrm{OH}}=R \ln 6$ ). Reaction (1) activation energies for $n$ - and iso- $\mathrm{C}_{3} \mathrm{H}_{7} \mathrm{OH}$ were also estimated from 
the $E_{1}$ value for $\mathrm{C}_{2} \mathrm{H}_{5} \mathrm{OH}$, with taking into consideration of the observation that the activation energy for molecular elimination of $\mathrm{HX}$ is practically independent of the chain length in n-alkyl radicals and increases by ca. $15 \mathrm{~kJ} / \mathrm{mol}$ upon $\alpha$-methylation of carbon. ${ }^{6,10}$ An analysis of Table IV leads one to conclude that the difference of threshold $\mathrm{C}_{\alpha}-\mathrm{C}_{\beta}$ bond dissociation and dehydration energies is far larger for $\mathrm{C}_{2} \mathrm{H}_{5} \mathrm{OH}$ and iso- $\mathrm{C}_{3} \mathrm{H}_{7} \mathrm{OH}$ than it is for $n-\mathrm{C}_{3} \mathrm{H}_{7} \mathrm{OH}$. As a result dehydration should play a far more important role in transformations of $\mathrm{C}_{2} \mathrm{H}_{5} \mathrm{OH}$ and iso- $\mathrm{C}_{3} \mathrm{H}_{7} \mathrm{OH}$ than with $\mathrm{n}-\mathrm{C}_{3} \mathrm{H}_{7} \mathrm{OH}$, for the $A_{1} / A_{2}$ ratio is practically the same for all the molecules. This conclusion is in agreement with experimental results (Tables II and III). It should be noted that although the activation energy of $\mathrm{C}_{\beta}-\mathrm{C}_{\gamma}$ bond cleavage in $\mathrm{n}-\mathrm{C}_{3} \mathrm{H}_{7} \mathrm{OH}$ is fairly high $\left(E_{\mathrm{C}_{\beta}-\mathrm{C}_{\gamma}}>E_{\mathrm{C}_{u}-\mathrm{C}_{\beta}}\right)$ this reaction makes a considerable contribution to IR MPE-induced decomposition of $\mathrm{n}-\mathrm{C}_{3} \mathrm{H}_{7} \mathrm{OH}$, probably because of a larger pre-exponential factor value, $A_{\mathrm{C}_{\beta}-\mathrm{C}_{\gamma}} / A_{\mathrm{C}_{\alpha}-\mathrm{C}_{\beta}}=10^{0,6^{6}}$. The structure of alcohols is thus in large part responsible for their transformations.

The dehydration to $\mathrm{C}_{\alpha}-\mathrm{C}_{\beta}$ bond dissociation reaction yield ratio, $\gamma$, depends on the density of absorbed radiation energy. Table $\mathrm{V}$ contains $\gamma$ values observed at various energy densities. When the focal distance is varied a decrease in energy density enhances low-energy dehydration reaction and conversely, increasing energy density favours the $\mathrm{C}_{\alpha}-\mathrm{C}_{\beta}$ bond dissociation reaction. Absorbed energy density can also be varied by varying the laser radiation frequency if it affects radiation absorption cross section. According to our data ${ }^{12}$ decreasing the cross section of absorption by $\mathrm{C}_{3} \mathrm{H}_{5} \mathrm{OH}$ on passing from $\nu_{1}=1050$ to $v_{2}=3650 \mathrm{~cm}^{-1}$ causes a change in the direction of molecular trans-

Table V $\phi\left(\mathrm{H}_{2} \mathrm{O}\right) / \phi\left(\mathrm{C}_{\alpha}-\mathrm{C}_{\beta}\right)$ ratios for IR MPE of alcohol molecules under collisionless conditions at various energy densities.

\begin{tabular}{llll}
\hline $\begin{array}{l}\text { Energy density, } \\
\text { relative units }\end{array}$ & 1.0 & 0.16 & 0.04 \\
\hline $\mathrm{C}_{2} \mathrm{H}_{5} \mathrm{OH}$ & 2.0 & 3.5 & - \\
$\mathrm{n}^{-} \mathrm{C}_{3} \mathrm{H}_{7} \mathrm{OH}$ & 0.75 & 1.0 & - \\
iso- $\mathrm{C}_{3} \mathrm{H}_{7} \mathrm{OH}$ & 1.5 & 2.1 & 3.8 \\
\hline
\end{tabular}

Relative energy density within the focal spot was estimated from the equation $I_{1} / I_{2}=$ $f_{2}^{2} / f_{1}^{211}$ where $I_{1}$ and $I_{2}$ are the energy densities for lenses with focal distances $f_{1}$ and $f_{2}$, respectively. 
formations: at $1050 \mathrm{~cm}^{-1}$, decomposition of $\mathrm{C}_{3} \mathrm{H}_{5} \mathrm{OH}$ proceeds via two channels, that is dehydration and $\mathrm{C}_{\alpha}-\mathrm{C}_{\beta}$ bond cleavage, whereas at $3650 \mathrm{~cm}^{-1}$ dehydration is only observed. This is a consequence of different competition conditions for the low- and high-energy channels at different radiation energy densities. In fact, excitation of molecules above the dehydration threshold, $E_{1}$, to levels that should be reached for $\mathrm{C}_{\alpha}-\mathrm{C}_{\beta}$ bond dissociation to occur, $E_{2}$, is more probable at higher radiation energy densities, that is at the radiation frequency corresponding to the higher absorption cross section value.

A comparison of data on alcohol vapour pyrolysis and IR laser photolysis under collisionless conditions shows that the two processes follow essentially different directions: while pyrolysis mainly goes as chain reactions of dehydrogenation of $\mathrm{C}_{2} \mathrm{H}_{5} \mathrm{OH}$ and iso- $\mathrm{C}_{3} \mathrm{H}_{7} \mathrm{OH}$ and the elimination of $\mathrm{CH}_{4}$ from $\mathrm{n}-\mathrm{C}_{3} \mathrm{H}_{7} \mathrm{OH}$, the principal paths of alcohol decomposition in IR photolysis are monomolecular reactions of dehydration and $\mathrm{C}_{\alpha}-\mathrm{C}_{\beta}$ bond dissociation whose relative importance depends on the alcohol structure and absorbed radiation energy density.

\section{Collisional conditions}

Gas heating caused by collisions results in an increase in the fraction of hot molecules compared with collisionless processes discussed above. This favours high-energy $\mathrm{C}_{\alpha}-\mathrm{C}_{\beta}$ bond dissociation reactions (Table VI). Heating in collisions is sufficient for the occurence of reactions between radicals and molecules with activation energies of about $40 \mathrm{~kJ} / \mathrm{mol}$ and radical dissociation reactions with activation energies of $90 \div 120 \mathrm{~kJ} / \mathrm{mol}$ (Table VII). The attainment of a constant dehydration to $C_{\alpha}-\mathrm{C}_{\beta}$ bond dissociation product yield ratio with increasing alcohol pressure is indicative of the occurrence of reactions under thermal equilibrium conditions at the same temperature (Table VI). The effective temperature $T_{\text {eff. }}$ in the reaction zone ${ }^{14}$ was estimated from the equation

$$
T_{\text {eff. }}=\frac{E_{2}-E_{1}}{R\left[\ln \gamma+\ln \left(A_{2} / A_{1}\right)\right]}
$$

to obtain values of $1200 \mathrm{~K}$ for $\mathrm{C}_{2} \mathrm{H}_{5} \mathrm{OH}, 1150 \mathrm{~K}$ for $\mathrm{n}-\mathrm{C}_{3} \mathrm{H}_{7} \mathrm{OH}$, and $1380 \mathrm{~K}$ for iso- $\mathrm{C}_{3} \mathrm{H}_{7} \mathrm{OH}$. The $E_{1}, E_{2}, A_{1}$, and $A_{2}$ values were taken from Table IV. 
Table VI Ratio $\gamma$ as a function of alcohol pressure $\mathrm{P}$ and ratio $\phi\left(\mathrm{H}_{2} \mathrm{O}\right) / \phi_{\Sigma}(\mathrm{C}-\mathrm{C})$ as a function of $n-\mathrm{C}_{3} \mathrm{H}_{7} \mathrm{OH}$ pressure.

\begin{tabular}{rllll}
\hline $\mathrm{P}_{\mathrm{Pa}}$ & $\mathrm{C}_{2} \mathrm{H}_{5} \mathrm{OH}$ & $\mathrm{n}-\mathrm{C}_{3} \mathrm{H}_{7} \mathrm{OH}$ & iso- $\mathrm{C}_{3} \mathrm{H}_{7} \mathrm{OH}$ & $\phi\left(\mathrm{H}_{2} \mathrm{O}\right) / \phi_{\Sigma}(\mathrm{C}-\mathrm{C})$ \\
\hline 10 & 2.5 & 0.76 & 1.5 & 0.46 \\
50 & 2.5 & 0.63 & 1.1 & 0.37 \\
100 & 2.4 & 0.56 & 0.90 & 0.36 \\
150 & 2.3 & 0.60 & 0.80 & - \\
200 & 2.1 & 0.59 & 0.75 & 0.35 \\
300 & 2.0 & 0.54 & 0.65 & 0.36 \\
400 & 2.0 & 0.48 & 0.62 & 0.30 \\
600 & 1.9 & 0.46 & 0.60 & 0.27 \\
800 & 2.0 & 0.46 & 0.60 & 0.26 \\
\hline
\end{tabular}

${ }^{\mathrm{a}}$ From $\mathrm{P}_{\mathrm{n}^{-} \mathrm{C}_{3} \mathrm{H}_{7} \mathrm{OH}}=250 \mathrm{~Pa}$ and at higher pressures, the product yield from reactions involving $\mathrm{C}_{\alpha}-\mathrm{C}_{\beta}$ bond dissociation is practically equal to $\phi\left(\mathrm{C}_{2} \mathrm{H}_{4}\right)$ under collisional conditions (the yield of radical $\mathrm{C}_{2} \mathrm{H}_{5}$ recombination products is smaller than $10 \%$ of $\phi\left(\mathrm{C}_{2} \mathrm{H}_{4}\right)$, and the contribution of radicals $\mathrm{C}_{2} \mathrm{H}_{5}$ to the formation of $\mathrm{C}_{2} \mathrm{H}_{6}$ (reaction (3)) is also only insignificant compared with decomposition reaction (20): the rate of the decomposition of radicals $\mathrm{C}_{2} \mathrm{H}_{5}{ }^{\mathrm{a}}$ is an order of magnitude higher than the raction (3) rate even at $\left.700 \mathrm{~K}\left(k_{3} \approx 10^{11} \exp (-40000 / \mathrm{RT})^{13}\right)\right)$.

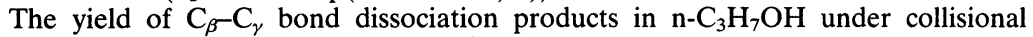
conditions is equal to the sum $\phi\left(\mathrm{CH}_{4}\right)+2 \phi\left(\mathrm{C}_{2} \mathrm{H}_{6}\right)$. As radicals $\mathrm{C}_{2} \mathrm{H}_{5}$ are mainly consumed in reaction (20) rather than (3) the major contribution to the formation of $\mathrm{C}_{2} \mathrm{H}_{6}$ comes from reaction (7).

Table VII Reactions involving radicals in IR MPE of alcohols under collisional conditions.

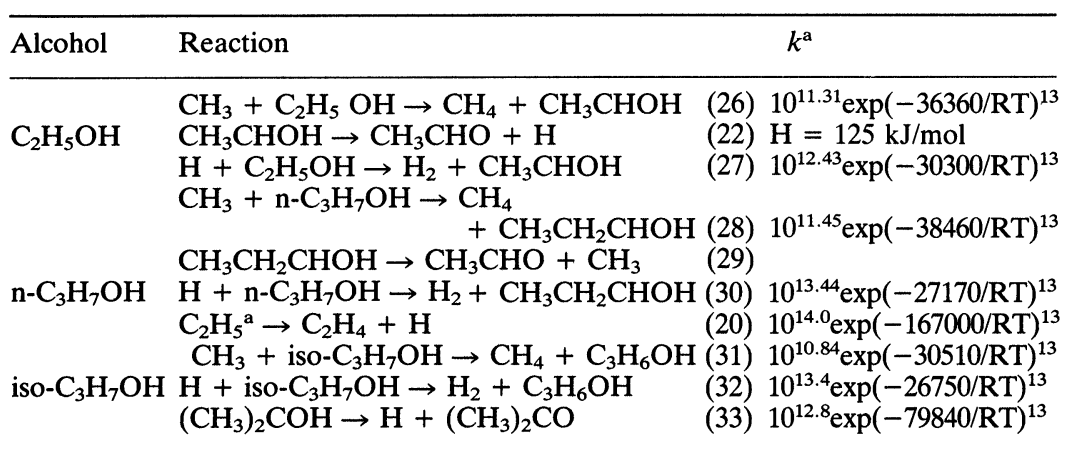

${ }^{\text {a }}$ Dimolecular reaction rate constants are given in $\mathrm{cm}^{3} \mathrm{~mol}^{-1} \mathrm{~s}^{-1}$, and monomolecular ones in $\mathrm{s}^{-1}$. 
The major processes under thermal equilibrium conditions are the same as in the absence of collisions, that is molecular dehydration and $\mathrm{C}_{\alpha}-\mathrm{C}_{\beta}$ bond dissociation reactions. Reactions of radicals with molecules which occur in collisional IR MPE of vapours do not initiate chain processes. In fact, the principal pyrolysis products formed in reactions (4) and (5), that is $\mathrm{CH}_{3} \mathrm{CHO}$ for $\mathrm{C}_{2} \mathrm{H}_{5} \mathrm{OH}, \mathrm{CH}_{3} \mathrm{COCH}_{3}$ for iso- $\mathrm{C}_{3} \mathrm{H}_{7} \mathrm{OH}$, and $\mathrm{CH}_{4}$ for $\mathrm{n}-\mathrm{C}_{3} \mathrm{H}_{7} \mathrm{OH}$, are only obtained in quantities below $15 \%$ of the total product yield. Under collisional IR MPE conditions, the ratio of products from reactions (4) and (5) which may be chain propagation steps to those from reaction (2) capable of chain initiation, that is $\phi\left(\mathrm{CH}_{3} \mathrm{CHO}\right) / \phi\left(\mathrm{C}_{\alpha}-\mathrm{C}_{\beta}\right)$ for $\mathrm{C}_{2} \mathrm{H}_{5} \mathrm{OH}, \phi\left(\mathrm{CH}_{3^{-}}\right.$ $\mathrm{CHO}) / \phi_{\Sigma}(\mathrm{C}-\mathrm{C})$ for $\mathrm{n}-\mathrm{C}_{3} \mathrm{H}_{7} \mathrm{OH}$, and $\phi\left(\mathrm{CH}_{3} \mathrm{COCH}_{3}\right) / \phi\left(\mathrm{C}_{\alpha}-\mathrm{C}_{\beta}\right)$ for iso$\mathrm{C}_{3} \mathrm{H}_{7} \mathrm{OH}$, is below unity. This evidences an only ineffective consumption of radicals $\mathrm{H}$ or $\mathrm{CH}_{3}$ in reactions between radicals and molecules. The chain propagation mechanisms is the same for all alcohols: one step is the dissociation of an alcohol radical with an about $100 \mathrm{~kJ} / \mathrm{mol}$ activation energy (reactions (4a) and (4b)), and the other one is radical recovery in the interaction of active centres $\mathrm{H}$ or $\mathrm{CH}_{3}$ with initial alcohol molecules (reactions (5a) and (5b)). Hydrogen atoms can participate in reaction (5a) or escape from the reaction zone by diffusion. Table VIII includes $\mathrm{H}$ atom diffusion to reaction (5a) rate ratios equal to $k_{\mathrm{d}} / k_{5 \mathrm{a}}\left[\mathrm{R}_{1} \mathrm{R}_{2} \mathrm{CHOH}\right]$ where $k_{\mathrm{d}}$ is the diffusion rate constant. The rate constant of diffusion from the reaction zone, $k_{\mathrm{d}}$, was calculated using the equation ${ }^{5}$

$$
k_{\mathrm{d}}=\frac{v_{H}}{\rho^{2} N \sigma_{H}}
$$

Where $v_{H}$ is the relative velocity of atoms $H$ and molecules $\mathrm{R}_{1} \mathrm{R}_{2} \mathrm{CHOH}$, $N$ the density of molecules per $1 \mathrm{~cm}^{3}$, $\sigma_{H}$ the cross section of $H$ atom collisions with $\mathrm{R}_{1} \mathrm{R}_{2} \mathrm{CHOH}$ and $\rho$ the reaction zone radius.

The latter quantity was calculated as ${ }^{5}$

$$
\rho=\sqrt[5]{\frac{3 \alpha V_{c} v}{4 \pi k_{1} N \sigma_{c s}}}
$$


Table VIII Hydrogen atom diffusion from the reaction zone to reaction (5a) rate ratio in IR MPE of $\mathrm{C}_{2} \mathrm{H}_{5} \mathrm{OH}$ and iso- $\mathrm{C}_{3} \mathrm{H}_{7} \mathrm{OH}$ molecules under thermal equilibrium conditions.

\begin{tabular}{lllrll}
\hline Alcohol & $\begin{array}{l}\mathrm{P}, \\
\mathrm{Pa}\end{array}$ & $\begin{array}{l}\rho, \\
\mathrm{cm}\end{array}$ & $\begin{array}{l}k_{\mathrm{d}}, \\
\mathrm{s}^{-1}\end{array}$ & $\begin{array}{l}k_{5 \mathrm{a}}\left[R_{1} R_{2} \mathrm{CHOH}\right] \\
\mathrm{s}^{-1}\end{array}$ & $k_{\mathrm{a}} / k_{5 \mathrm{a}}\left[R_{1} R_{2} \mathrm{CHOH}\right]$ \\
\hline $\mathrm{C}_{2} \mathrm{H}_{5} \mathrm{OH}$ & 400 & 0.5 & 2.0 & 21.8 & 1.1 \\
iso- $\mathrm{C}_{3} \mathrm{H}_{7} \mathrm{OH}$ & 500 & 0.11 & 37.0 & 10.0 & 3.7 \\
\hline
\end{tabular}

where $\alpha$ is the degree of conversion of $\mathrm{R}_{1} \mathrm{R}_{2} \mathrm{CHOH}$ in reaction (1), $V_{c}$ the cell volume,

$v$ the mean thermal velocity of $\mathrm{R}_{1} \mathrm{R}_{2} \mathrm{CHOH}$ molecules, and $\sigma_{c s}$ the gas kinetic cross section of $\mathrm{R}_{1} \mathrm{R}_{2} \mathrm{CHOH}$.

Table VIII shows that the rate of hydrogen atom diffusion from the reaction zone is comparable with or exceeds the reaction (5a) rate. Diffusion of $H$ atoms from the hot zone to the cold one results in chain termination because the dissociation of $\mathrm{R}_{1} \mathrm{R}_{2} \mathrm{CHOH}$ radicals (reaction (4a)) is hindered in that zone its activation energy being fairly high, of about $100 \mathrm{~kJ} / \mathrm{mol}$.

The participation of $\mathrm{CH}_{3}$ radicals in chain propagation reaction (29) involving $\mathrm{n}-\mathrm{C}_{3} \mathrm{H}_{7} \mathrm{OH}$ is reduced because of effective recombination of these radicals (reaction (7)). In fact depending on alcohol vapour pressure, IR MPE of $n-\mathrm{C}_{3} \mathrm{H}_{7} \mathrm{OH}$ is characterized by $\phi\left(\mathrm{C}_{2} \mathrm{H}_{6}\right)$ values higher than or comparable with $\phi\left(\mathrm{CH}_{4}\right)$ (Figure 1). The high recombination probability for radicals $\mathrm{CH}_{3}$ is the result of the high concentration of these particles. The quadratic law for $\mathrm{CH}_{3}$ recombination follows from a linear dependence of $\beta$ on the initial $n-\mathrm{C}_{3} \mathrm{H}_{7} \mathrm{OH}$ concentration (Figure 4) where $\beta$ is the ratio of $\mathrm{CH}_{4}$ formation rate to the square root of $\mathrm{C}_{2} \mathrm{H}_{6}$ formation rate. The $\mathrm{CH}_{4}$ and $\mathrm{C}_{2} \mathrm{H}_{6}$ formation rates are calculated by dividing the concentrations of these particles in the reaction zone by the reaction time taken to be equal to the time of diffusion of alcohol molecules from the reaction zone. The dependence

$$
\beta=\frac{k_{28}\left[\mathrm{n}-\mathrm{C}_{3} \mathrm{H}_{7} \mathrm{OH}\right]}{\sqrt{k_{7}}}
$$

can only exist with the quadratic law of radical recombinations. The dependence of the reaction (7) rate on the third body, $M$, concentra- 


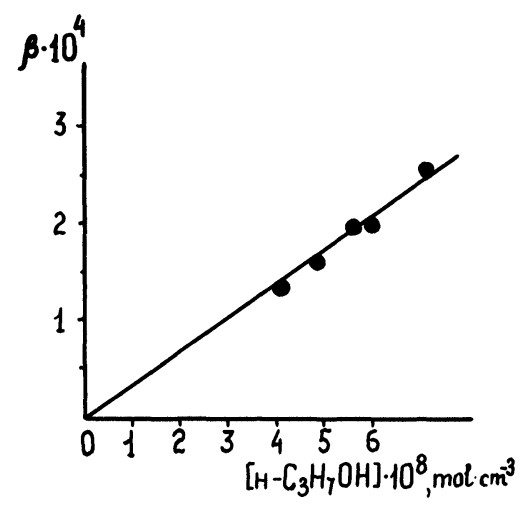

Figure 4 The dependence of $\beta$ on $\left[\mathrm{n}-\mathrm{C}_{3} \mathrm{H}_{7} \mathrm{OH}\right]$.

tion is only a weak one over a narrow pressure range $\mathrm{e}^{15}$ and therefore, it can be ignored. The straight line shown in Figure 4 has a slope of $3.3( \pm 0.3) \cdot 10^{3}$. Using the value $k_{28}=5.0 \cdot 10^{9} \mathrm{~cm}^{3} \mathrm{~mol}^{-1} \mathrm{~s}^{-1}$ at $1150 \mathrm{~K}$ in Eq. (37) we find the $\mathrm{CH}_{3}$ radical recombination rate constant to be equal to $2.3( \pm 0.4) \cdot 10^{12} \mathrm{~cm}^{3} \mathrm{~mol}^{-1} \mathrm{~s}^{-1}$. Listed in Table IX are the radical $\mathrm{CH}_{3}$ concentrations calculated using the quasistationary concentration technique for thermal equilibrium conditions and the ratios $\phi\left(\mathrm{CH}_{4}\right) / \phi\left(\mathrm{C}_{2} \mathrm{H}_{6}\right)$ obtained as

$$
\frac{\phi\left(\mathrm{CH}_{4}\right)}{\phi\left(\mathrm{C}_{2} \mathrm{H}_{6}\right)}=\frac{k_{28}\left[\mathrm{n}-\mathrm{C}_{3} \mathrm{H}_{7} \mathrm{OH}\right]}{k_{7}\left[\mathrm{CH}_{3}\right]}
$$

It follows that IR MPE of alcohol molecules under thermal equilibrium conditions does not initiate chain processes because of diffusion

Table IX Steady-state concentrations of radicals $\mathrm{CH}_{3}$ and $\phi\left(\mathrm{CH}_{4}\right) / \phi\left(\mathrm{C}_{2} \mathrm{H}_{6}\right)$ ratios for $\mathrm{n}-\mathrm{C}_{3} \mathrm{H}_{7} \mathrm{OH}$ under thermal equilibrium conditions.

\begin{tabular}{|c|c|c|c|}
\hline \multirow{2}{*}{$\begin{array}{l}\mathrm{P}_{\mathrm{n}-\mathrm{C}_{3} \mathrm{H} 7 \mathrm{OH}} \\
\mathrm{Pa}\end{array}$} & \multirow{2}{*}{$\begin{array}{l}{\left[\mathrm{CH}_{3}\right] \cdot 10^{-10},} \\
\mathrm{~mol} / \mathrm{cm}^{3}\end{array}$} & \multicolumn{2}{|c|}{$\phi\left(\mathrm{CH}_{4}\right) / \phi\left(\mathrm{C}_{2} \mathrm{H}_{6}\right)$} \\
\hline & & experimental & calculated \\
\hline 333 & 1.28 & 0.53 & 0.63 \\
\hline 399 & 1.38 & 0.63 & 0.67 \\
\hline 465 & 1.47 & 0.73 & 0.75 \\
\hline 532 & 1.56 & 0.79 & 0.81 \\
\hline 665 & 1.72 & 1.03 & 0.93 \\
\hline
\end{tabular}


of $\mathrm{H}$ atoms from the reaction zone and recombination of $\mathrm{CH}_{3}$ radicals whose high concentration makes the latter process capable of competing with chain propagation reactions.

\section{CONCLUSIONS}

Monomolecular dehydration and $\mathrm{C}_{\alpha}-\mathrm{C}_{\beta}$ bond dissociation reactions are the major processes initiated by IR MPE of $\mathrm{C}_{2} \mathrm{H}_{5} \mathrm{OH}, \mathrm{n}-\mathrm{C}_{3} \mathrm{H}_{7} \mathrm{OH}$, and iso- $\mathrm{C}_{3} \mathrm{H}_{7} \mathrm{OH}$ under both collisionless and collisional conditions. Conversely, pyrolysis of the alcohols is dominated by chain reactions of dehydrogenaton of $\mathrm{C}_{2} \mathrm{H}_{5} \mathrm{OH}$ and iso- $\mathrm{C}_{3} \mathrm{H}_{7} \mathrm{OH}$ and splitting off of $\mathrm{CH}_{4}$ from n- $\mathrm{C}_{3} \mathrm{H}_{7} \mathrm{OH}$. The dehydration to $\mathrm{C}_{\alpha}-\mathrm{C}_{\beta}$ bond dissociation rate ratio is determined by the structure of alcohol molecules and either absorbed radiation energy density under collisionless conditions or effective reaction zone temperature under thermal equilibrium conditions. Absorbed radiation energy densities and temperatures being the same the contribution from the low-energy dehydration reaction to the total yield of alcohol conversion products is far higher for $\mathrm{C}_{2} \mathrm{H}_{5} \mathrm{OH}$ and iso- $\mathrm{C}_{3} \mathrm{H}_{7} \mathrm{OH}$ than for $\mathrm{n}-\mathrm{C}_{3} \mathrm{H}_{7} \mathrm{OH}$. This is explained by a larger difference of threshold energies for the bond cleavage and dehydration reactions characteristic of the first two alcohols. Increasing radiation energy density and temperature enhances $\mathrm{C}_{\alpha}-\mathrm{C}_{\beta}$ bond dissociation reactions, while decreasing them favours the dehydration.

\section{References}

1. J. A. Barnard and H. W. D. Hughes, Trans. Farad. Soc. 56, 55 (1960).

2. J. A. Barnard and H. W. D. Hughes, Trans. Farad. Soc. 56, 64, (1960).

3. J. A. Barnard and H. W. D. Hughes, Trans. Farad. Soc. 56, 72, (1960).

4. Yu. N. Molin, V. N. Panfilov and A. K. Petrov, Infrared Photochemistry (Novosibirsk, Nauka Publishers, 177, 1985).

5. G. P. Zhitneva and S. Ya. Pshezheteskii, z.Khimiya Vysokikh Energii, 19, 176, (1985).

6. W. Tsang, Int. J. Chem. Kinet. 8, 193, (1976).

7. G. P. Zhitneva and I. A. Markina, z.Khim. Vys. Ener. 22, (1988).

8. L. V. Gurvich, G. V. Karachintsev and V. N. Kondrat'ev, Chemical Bond Dissociation Energies. Ionization Potentials and Electron Affinities (Moscow, Nauka Publ., 1974).

9. S. W. Benson, Thermochemical Kinetics (Moscow, Mir Publ., 1971).

10. P. J. Robinson and K. A. Holbroock, Unimolecular Reactions (Moscow, Mir Publ., 1975). 
11. D. R. Keefer and J. E. Allen, Chem. Phys. Lett. 43, 394 (1976).

12. G. P. Zhitneva, z.Khim. Vys. Ener. 22, (1988).

13. V. N. Kondrat'ev, Rate Constants of Gas Phase Reactions. Handbook (Moscow, Nauka Publ., 1970).

14. C. Steel, Chem. Phys. Lett. 62, 121 (1979).

15. P. D. Pacey and J. H. Wimalasena, J. Phys. Chem. 84, 2221 (1980). 